\title{
ARTIFICIAL INTELLIGENCE AND ITS IMPACT ON LABOUR RELATIONS IN ESTONIA
}

\author{
Kristi Joamets ${ }^{1}$, Archil Chochia ${ }^{2}$
}

\begin{abstract}
The third industrial revolution, the digital revolution, affected economy and thus labour relations, too. Now the so-called fourth revolution, the artificial intelligence (AI) revolution, will cause further massive changes in the labour market. This is not just about the caution that robots will replace all employees, but this also raises a question about new skills the labour market requires the employees to have. Scientific literature and the EU policy documents do not cover the AI - labour market issues in a unified approach, however welcoming the development of new technologies on the one hand, with concerns about weakening the labour force by jobs loses, on the other hand. The article elucidates the AI revolution and analyses the AI influence on labour market, specifically identifying the new skills required, based on relevant scientific literature and the EU policy documents. Considering the AI impact on labour relations, continuous alteration of skills and knowledge offered should be of special concernit is not only about a labour relation per se, new models emerge all the time in the labour market. The authors also investigate the impact of AI on the Estonian labour market, i.e. whether the AI's effects appear as disastrous as expected or simply a welcome development for the welfare of the state. The article discusses how AI impacts labour relations and which professions fall in a greater risk of disappearing and, more specifically, the AI's influence on the Estonian labour market.
\end{abstract}

KEY WORDS: Artificial Intelligence, Estonia, European Union, Fourth Revolution.

\section{INTRODUCTION}

The digital revolution is replaced by the AI revolution making thus economy more influenced by technologies than ever before. Shook and Knickrehm (2018) described the AI revolution as "a revolution in which intelligent technology meets human ingenuity to create the future workforce, one that promises previously unobtainable sources of growth and innovation." AI is defined as "software systems designed by humans that, given a complex goal, act in the physical or digital world by perceiving

\footnotetext{
${ }^{1}$ TalTech Law School, Tallinn University of Technology, Ehitajate tee 5, 19086 Tallinn, Estonia, e-mail: kristi.joamets@taltech.ee.

${ }^{2}$ TalTech Law School, Tallinn University of Technology, Ehitajate tee 5, 19086 Tallinn, Estonia, e-mail: archil.chochia@taltech.ee.
} 
their environment through data acquisition, interpreting the collected structured or unstructured data, reasoning on the knowledge or processing the information, derived from this data and deciding the best action(s) to take to achieve the given goal" (European Commission, 2019a, p. 36). Such a wide definition allows the use of term of $\mathrm{AI}$ in every branch of economy, including the labour market.

Scientific literature brings out serious estimations on the extent to which AI might affect labour relations in different countries: e.g., $47 \%$ in the US, $35 \%$ in the UK, 36\% in Finland, 69\% in India, and 77\% in China (Pajarinen, Rouvinen, 2014; EESC, 2017a, p. 11; Kim, et al., 2017, p. 3). According to David (2017, p. 77), approximately $55 \%$ of the jobs will be performed by computers in the future. These are the numbers the countries cannot deny, and need to consider them in their policies. Similar concerns related to AI technologies, simply replacing humans, are widespread among the general public as well, or as Laura Delponte $(2018$, p. 34) underlines, "the largest public fear is that AI technologies can soon replace a wide variety of human jobs, resulting in mass scale unemployment, ever increasing inequality and social unrest". In addition, this is not only the concern of elder generation but is shared also among young people (International Labour Organization, 2020 , p. 15) However, according to the OECD data, $9 \%$ of the jobs are expected to disappear (OECD, 2017, p. 107). It is evident that some professions or positions are in a bigger risk of disappearing than the others, but the main the impact of AI will manifest itself as a demand for new skills that the employee must have in order to use AI tools. Scientific literature and the EU policy documents do not approach the AI - labour market relation in the like manner. Both welcome development of the new technologies on the one hand, and raise their concerns about the labour force potentially losing their jobs, on the other hand.

This paper follows empirical research relying on scientific literature and EU policy documents. The analyses explores the general principle of democracy in the context of the restriction of employees rights while evaluating the existence of a restriction per se and its justification. The research considers the traditional legal hierarchy of laws exploring the EU law and policies related to AI and job market, including new digital skills of future employees, applicable in the EU member states policies and lawmaking.

The article analyses the influence of AI on labour market, specifically discussing the new skills required, relying on scientific literature and the EU policy documents. The questions raised in the research, are "What is the 
future of $\mathrm{AI}$ in the labour market", "Does it only take the employee the job or does it mean that future jobs will just be changed?". Moreover, this is an attempt to verify the fears from AI declared so often in the literature and media, whether it is necessary to fight against $\mathrm{AI}$ in the labour market or accept it as a obvious development in economy and labour relations. The paper begins with the empirical research on the impact of technology on labour market and the role of $\mathrm{AI}$ in this process. The paper attempts to show that such development is impossible to stop and that the effects are not as negative as often assumed. Additionally, the new skills needed to manage these new developments are discussed here altogether with discussing on how labour market should adapt to these changes. After that the new AI-based jobs are discussed with the EU policies demanding new skills in digital competencies.

\section{AI AND THE LABOUR MARKET?}

Technologies per se have already tremendously affected the labour relations and we have not even noticed the full scale of the process, perhaps. History proves how manufacturing influenced society, including labour relations. The society has undergone several technological revolutions; the latest of them was industrial revolution, digital revolution, and now, the AI revolution. Tracking back to the 1980s, Karl-H. Ebel (1987, p. 43) argued that "the effects of robotisation on employment may be considered at the plant, enterprise and macro-economic levels. At the plant level the industrial robot is generally a direct replacement of human labour". Development of technologies cannot be stopped and we only can just to accept their influence not only on the ways how the companies operate, sell their products/services and are managed but also on the employment patterns (Makridakis, 2017, p. 53). There is also a shift apparent in the EU's approach and certain actions to tackle the problem of protecting workers in the socalled "gig economy". The new legislation focuses on the key aspects such as increased transparency, better protection for new forms of employment and new rules for probationary period and training. It introduces new demands and minimum rights for the workers involved and addresses the issues of adequate and stable work and compensation environment (European Parliament, 2019). COVID-19 virus has proved that variety of employment tasks are can conducted on a distance, however requiring the employee to be able to use digital means and at the same time, to manage those communicating and controlling on a distance. 
AI stimulates the economy: it lowers production costs and increases the production of goods (SPARC, 2013, p. 6; Szczepański, 2019; PwC, 2018; Anderson, 2019). This means that labour can be substituted for capital (see Pajarinen, Rouvinen, 2014, p. 1), and it is cheaper for the company. There is no doubt about that "innovation and creativity are important" for the "sustainable and competitive social market economy" but applying them requires to "achieve a balance between promoting the economic and social benefits of these new developments" (EESC, 2016, p. 5). However, people should be prepared to work in the "knowledge economy", including also technologies and computers (Breslow, 2015, p. 421).

Today, technological development creates new professions and some other just disappear - that means that AI can replace a human employee. The situation is characterised as labour- market polarisation: low and middle-skilled workforce is replaced by robots (see Pajarinen, Rouvinen, 2014, p. 5; DeCanio, 2016, p. 281; Kerikmäe, et al., 2018; Kim, et al., 2017, p. 2; Dau-Schmidt, 2017, p. 84ff; Foresight Center, 2018). However, it will still take a long time for the robots completely replace employees. By now, the employees are needed to regulate, guide and control the AI and this means just a modification of job positions.. Technologies merely "produce a quality shift in jobs" (David, 2017) demanding new skills. David further states that workers may no longer carry out some tasks, whereas others will appear because of new activities (David, 2017, p. 79). Fleming (2020) states that "While occupations change slowly - over years and even decades - tasks become reorganized at a much faster pace". Based on scientific literature we may argue that the prognoses about AI entering the labour market are more or less speculative. Today, we already know and have expectations about what AI can do, but we also see a real risk for employees working mainly in industries. Using $\mathrm{AI}$ in other spheres, such as services, needs additional analyses of reliability and user-friendliness. For a long time, AI will remain just a helping tool for employees and the employees today need their retraining to guide and control the AI. Therefore, employees are required to have the digital skills. Unfortunately, according to the data of European Commission, $47 \%$ of the EU population does not possess sufficient digital skills, however in the near future, $90 \%$ of jobs will require some level of digital skills (European Commission, 2019b). Nevertheless, European Commission states that "A strong digital economy is vital for innovation, growth, jobs and European competitiveness. The spread of digital is having a massive impact on the labour market and the type of skills needed in the economy and society. It is changing the structure of employment, 
leading to the automation of "routine" tasks and to the creation of new and different types of jobs." (European Commission, 2019b; Sharma, 2019; Roe, 2018) According to Fleming (2020), "technology reduces the cost of some tasks because they can be done in part by AI, the value workers bring to the remaining tasks increases. Those tasks tend to require grounding in intellectual skill and insight-something AI isn't as good at as people." However, granting new skills takes time and this subsequently also delays implementing the AI in a labour market. Punie's description about ICTlearning fits very well to characterise also the application of AI in labour market: "This will not happen by itself. It needs investment, resources, innovation, research, multi-stakeholder involvement, trial-and- error and many more social and institutional changes. And this will probably take longer than expected." (Punie, 2007, p. 195) Furthermore, we cannot forget that using AI in labour relations should not always push people out of work but ought to improve the quality of their work, for example by allowing them to work less or in better conditions (Viola, 2018, pp. 5-6).

Certainly, to guide and control AI, an employee needs additional digital skills and the ability to make decisions regarding the robot (see Autor, Levy, Murnane, 2003, pp. 1285, 1322). This needs the new skills like problemsolving, complexity, creativity, inquiry and analyses, critical thinking, teamwork, etc. (Breslow, 2015, p. 422) Not only digital skills, but also other skills are required to support the innovation in a labour market. Muller explains that "we need a human-in command approach to AI, where machines remain machines and people retain control over these machines at all times" (EESC, 2017b). Additionally, not all the positions/professions but only single tasks will be taken over by the robots (see more Arntz, Gregory, Zierahn, 2017, p. 160).

Replacing fully, or partly, an employee can cause social and legal problems. It is emphasised that "labour market policies must protect and re-skill/up-skill those who will be affected by digitalisation" (EESC, 2016, p. 5). Since the process of automation has a greater impact on low-income jobs and jobs that do not need advanced skillset, retraining and welfare for these people is a major challenge. Skill-biased technological change lowers the demand for low-skilled workers. (McIntosh, 2002) Retraining will be key in these situations and countries need to be ready by already focusing on prevention activities, such as "nudging" people towards professions that require the skillset that is needed in case industries switch to more automated processes. Delponte $(2018$, p. 8) suggests that "adaptation of welfare and education systems will be necessary to protect 
the people whose skills become obsolete and to mitigate the amplification of power asymmetries and inequalities generated by increased automation". However, as long as repetitive (routine) tasks are being replaced, the topic has still not received much attention; however, once there is a risk that also high-skilled employees will become automated, the situation will be taken much more seriously, because this could mean that a doctor, a teacher, a nanny, a trainer, etc., can be replaced by a robot, and this could pose a real challenge. Pajarinen and Rouvinen $(2014$, p. 3) point out that "in Finland large occupations most susceptible to computerisation include shop sales assistants, secretaries, bank tellers, and office clerks. In the other end, large occupations least susceptible to computerisation include nurses, childcare workers, social workers, and counselling professionals."

Giving cognitive tasks to robots is not so well supported - it is considered a challenge rather than just an easy solution (Frey, Osborne, 2017, pp. 258, 260). Jarrahi argues that human decision-making is not always a direct result of deliberate information gathering and proceeding but arises from the subconscious in the realm of intuition. At the same time, analytic approaches to decision-making rely on the depth of information. These two systems of decision-making are parallel systems to address various contingencies more effectively. AI systems support an analytic approach to decision-making and are less capable of understanding common-sense situations, and furthermore, compared to humans, they are less viable than humans are in uncertain or unpredictable environments, especially outside the predefined domain of knowledge. Therefore, humans are more likely to perform better at decisions that require an intuitive approach. Jarrahi therefore concludes that "though AI does have superior qualities, humans retain the comparative advantage when addressing uncertainty and equivocality in decision-making as they can leverage their superior intuition, imagination, and creativity" (Jarrahi, 2018, pp. 579-580).

In making decisions in a situation of uncertainty (e.g. because of lack of information about internal and external organisational environments), $\mathrm{AI}$ and other intelligent technologies can assist human decision-making with predictive analysis. The AI system can generate fresh ideas through probability and data-driven statistical inference approaches and can identify relationships among many factors, which make human decisionmakers more effective in collecting and acting upon new sets of information. (Jarrahi, 2018, p. 580)

Jarrahi therefore speaks about a "partnership between human decisionmakers and AI" (and not a replacement), which can play out in two ways: 
1. Human and AI technologies can collaborate to deal with different aspects of decision-making. AI is likely to be well positioned to tackle complex issues (using analytical approaches). Humans can focus more on uncertainty and equivocality, using more creative and intuitive approaches;

2. Even the most complex decisions - in which AI has a comparative edge - are likely to require elements of uncertainty and equivocality, which compels human involvement. Therefore, humans and AI will play a combined role in almost all complex decision-making (Jarrahi, 2018, pp. 582-583).

When AI supports humans, it may demand faster and sometimes even higher analytical skills from humans, because the latter have to be able to determine and understand whether a robot made a correct calculation or a conclusion. Regardless, the competence development plays an important role: "employee should be able to take over another position if the current one disappears." (Houtcoop, 2002, p. 318).

Then again, the literature offers diverging statements: some authors argue that regarding the positions which need originality and social skills, the so-called cognitive skills, automation is more complicated (EESC, 2017a, p. 13; Autor, Levy, Murnane, 2003, p. 1284), while the others state that also such employment positions which require high-order thinking can be replaced or supported by the AI (see, e.g., Wright, Schultz, 2018, p. $825)$. Huang and Rust (2018, p. 168) analysed how and why AI can replace humans in the specific types of works which require different intelligences (mechanical, analytical, intuitive and empathetic) and concluded that "the advance of $\mathrm{AI}$ in all four intelligences creates opportunities for innovative human-machine integration for providing service but also results in a fundamental threat to human employment".

Wright and Schultz (2018) stated that to the extent to which a position is routine, skill-based and social, there are three variables, which will affect the immediacy and likelihood that automation will distract particular professions. They concluded that "lower skilled labour markets that require less social interaction and are predominated by routine, where caring for others is less important" will be contracted by automation. Middle-skilled jobs (such as clerical work and manufacturing) are declining while low- and high-skilled jobs are increasing. Furthermore, middle-skilled workers will move toward less skilled, service-oriented positions, which leads to further wage erosion. (Wright, Schultz, 2018, p. 825) They further expect that 
employees who work in professional careers that emphasise high skills, low routine and high social aspects will benefit most from automation. This will lead to a depressed earning of less-educated, routine-based workers and will benefit high-educated, low routine-based workers. (Wright, Schultz, 2018, p. 826) Szczepański $(2019$, p. 7) explains the AI impact as the following: "Rising demand for high-skilled workers capable of using AI could push their wages up, while many others may face a wage squeeze or unemployment. This could affect even mid-skilled workers, whose wages may be pushed down by the fact that high-skill workers are not only more productive than they thanks to the use of AI are but are also able to complete more tasks. The changes in demand for labour could therefore worsen overall income distribution by affecting overall wages." In addition, DeCanio states that expansion of AI will cause wages depressed over time. He believes that this will increase the measured inequality unless the returns to robotic assets are broadly spread across the population (DeCanio, 2016, p. 289).

Wilson, Daugherty and Morini-Bianzino (2017) present three categories of new, unprecedented jobs, which will come up due to AI and will not replace old roles. They created three new categories - 'Trainers', 'Explainers' and 'Sustainers' - which will be necessary in the future of AI. 'Trainers' will teach AI systems how they should perform and the AI algorithms how to mimic human behaviour; 'Explainers' will explain the inner workings of a complex algorithm and understand the causes of behaviour, if a system made a mistake; and 'Sustainers' will help to ensure that AI systems are operating as designed (Wilson, Daugherty, Morini-Bianzino, 2017, p. 14).

\section{AI, NEW MODELS OF LABOUR RELATIONS AND NEW SKILLS}

Another important aspect related to labour relations and AI is the fact that labour market and labour relations are changing. In general, the situation could be described as a situation when a common labour relation between the employer and the employee expressed by the labour contract protecting the employee is replaced by another type of civil contracts, in which the employee is an individual person who sells his/her knowledge and skills or offers a service. A person who works does not have to be an employee anymore, and is instead an 'independent contractor, 'associate', 'tasker', 'partner'" (EESC, 2016, p. 2). In 2016, the European Economic and Social Committee wrote in its opinion that "the changing nature of work and employment relationship is developing rapidly. The challenge for the $\mathrm{EU}$ is to encourage innovation, technological development and creativity to 
drive and deliver positive outcomes for a sustainable and competitive social market economy." (EESC, 2016, p. 2) This statement supports using AI in labour relations, but the question is - in which way? Another aspect that should be considered is that some jobs will disappear also because of new patterns in selling a job.

Dau-Schmidt argues that:

"we need to abandon outmoded legal definitions of who is an employee and who is an 'independent contractor'. In their place we should adopt two unifying principles for coverage: the avoidance of 'regulatory arbitrage' so that decisions on the organization of production are made on the basis of real economic advantages rather than just on the basis of avoiding legislative responsibility for the provision of benefits under protective legislation to the cheapest cost avoider so as to minimize the burden of fulfilling the promises of protective legislation" (Dau-Schmidt, 2017, p. 64).

It is evident that, there is not a clear position on the EU level, literature or in the legal acts. It seems that, on the one hand, an employee is pushed to be an independent contractor; while on the other hand, there is a demand that someone should protect such person. And then, there is a threat of AI to the person as well. In the context of protecting an employee against $\mathrm{AI}$, it must be clear which legal relationships is considered. Beyond any doubts, AI affects the market of new labour relations as well, but it is more complicated to argue that AI will take somebody's job and this person needs then a special protection, and it should be decided then who must provide such protection, because new labour relations do not involve an employer anymore. As clients- passengers, we are used to buy plane or bus tickets online and get annoyed when we encounter a service that is not digital. For us, as clients, it does not matter whether drones are replacing delivery service employees or that we have to use self-check-in at the airport and self-service checkouts in supermarkets. These new digital services can be supervised by the contract employment but some of them can be easily performed by new labour relations because often the work is temporary and can be done in a distance.

When talking about new labour relations then perhaps, two of the most popular are 'work on demand' and 'crowdsourcing'. Under 'work on demand', a company provides a proprietary app which the customers can use to arrange for provisions of services (e.g. transport, waiter services, cleaning, errands, secretarial work, etc.). The organising company establishes 
certain parameters on the transaction, such as pre-approving the workers, setting the pricing structure, specifying certain expectations of workers and transfers the payment for the services, but retains a portion for their management fee. Such providers are, for example, TaskRabbit, Handy, Uber and Lyft. Although Uber or Lyft exercise some control over the drivers, the drivers are independent contractors (Dau-Schmidt, 2017, p. 74).

Upwork is a platform for hiring freelancers who offer their services on a platform for various categories, such as IT \& Networking, Writing, Sales \& Marketing, Design \& Creative, Translation, Legal, Accounting \& Consulting, Engineering \& Architecture, etc. The freelance worker is paid by hour or as a fixed-price-job for a project. The freelancers can be independent contractors or employees of the client; the client is responsible for the proper classification of the freelancer. (Upwork, n.d.) Platform Handy operates in a similar manner but specialises in cleaning and handyman tasks. At the same time, Handy is not the employer of the professionals but only connects independent service professionals with customers. (Handy, n.d.)

'Crowdsourcing' is a similar online matching system of service consumers with workers through a proprietary app. By crowdsourcing, the work is not only assigned but it is also performed online. Platforms for crowdsourcing are, e.g., Crowdflower and Clickworker or Amazon Mechanical Turk (AMT). For example, through AMT, Amazon provides an electronic bulletin board for subscribing parties to post and bid on jobs. Amazon maintains certain minimum standards for participation, a system of evaluation for each worker, a dispute resolution system and a payment clearinghouse for the work but keeps itself a percentage of the bill. If a person wishes to crowdsource work, it lists a "request" for a specified job, the rate of pay and a performance deadline. Crowd-workers who subscribe to the platform then can apply to do the work and are either accepted or rejected. When the accepted crowd-worker completes the task, he submits the work to the requester. The requester then has the right to accept the work and pay the prescribed fee, or reject the work and not pay the fee, and regardless of that, he can keep the work-product. As the crowdsourcing rates are rather low, requesters sometimes assign the same tasks to various crowd-workers and then reject the work that does not match that of other crowd-workers and do not pay for the work. (Dau-Schmidt, 2017, p. 75)

In most cases today, 'work on demand' and also 'outsourcing' are used for lower- and middle-skilled work, which means that these are the jobs that will be the first to be replaced by AI. Engineers can design computers or robots that execute routine tasks, such as organising, storing, retrieving, 
which are mostly the tasks of middle-skill/middle-pay jobs (e.g. clerical work, translating, bookkeeping, repetitive production jobs).

Considering the development of AI, it is important to start working out the relevant social security systems already today. Fudge (2007, p. 31) states that "the new discourse of labour rights also involves a realignment of the relationship between social rights and the market, and a reconceptualization of the juridical nature of social rights". Low-skilled workers should be gradually retrained, in order to practice and analyse the efficiency of the process - will low- and middle-skilled workers be able and willing to adapt to new technology, will the state have enough sources and knowledge to retrain workers, and will it support the retraining at all or leave it the employer's responsibility. Will the system be sustainable and applicable? Protection of low and middle-skilled workers does not mean to keep their jobs, but as discussed above, give them an opportunity to learn new skills and find a new job, preferably as an instructor to the AI tool producing the same goods. Furthermore, all new labour relations require some kind of digital skills and these skills must be developed continuously.

\section{THE IMPACT OF AI ON THE ESTONIAN LABOUR MARKET}

The OECD Employment Outlook 2017 estimates that only 6\% of employments will disappear in Estonia, compared to the $9 \%$ in other member states (OECD, 2017). This shows that in Estonia the risk of losing a job because of $\mathrm{AI}$ is smaller than in other countries. Understanding the impact of $\mathrm{AI}$ on the Estonian labour market requires an understanding of the legal model of its labour relations, evaluating the existing development plans of $\mathrm{AI}$ in the state policy, and analysing the practice of labour relations.

The impact of AI differs in large and small countries, as small countries do not have so many industries as the big countries do. For example, in Estonia with its population of 1.3 million, it will not have as big an effect as in larger states such as Germany, France or the US. Also, in Estonia most young people acquire university-level education, which means that they are highly educated and able to learn additional digital skills to manage AI. As a small state, Estonia does not have big industries. Furthermore, the new Employment Contract Act was adopted in Estonia in 2009 to regulate the labour relations of micro- and small enterprises, which demonstrates that the Estonian labour market can be described by small companies who employ; and this means that the law considers employer and employee as equal parties in contracts regulating the labour relations. Trade unions 
are not popular and neither there are collective agreements. As the labour costs are too high, employers hire as few employees as possible. Estonia has enforced by law a minimum salary, which rises every year but is too small from the employees' point of view and the employer must pay more to get an employee. To avoid high labour costs, employers have resorted to underreporting wages, paying the so-called "envelope wages", but as the state started a serious fight against such salaries, new tools have emerged in the labour market: working as an independent contractor or selling the knowledge and skills through own company. A number of people selling their services not as employees is increasing, for example, from $7.9 \%$ in 2008 to $10.2 \%$ in 2017 (Piirist, 2018, p. 5). Work on demand is also popular, whereas outsourcing is not as common. In all these cases, other civil contracts are used instead of employment contracts, which frees the employer from several obligations and costs. According to Estonian labour law, an employee is a natural person who performs work tasks for another person, the employer, and is subordinate to the employer; the employer must remunerate the employee for such work and ensure appropriate working conditions and tools. A person working under other contracts is independent and is responsible him/herself for the working conditions and tools.

Work on demand is used a lot in the service sector - mostly in hiring waiters and dishwashers by hotels and restaurants, but also in hiring handymen, cleaners, sorters, bundlers, and others by other service companies. These are low- and middle-skilled positions, which likely will be the first AI replaced. However, the authors do not yet see that hotels or other companies are ready for that today. For example, in 2018, two big companies in the clothing industry moved their factories out of Estonia, whereas the problem was not the lack of workers but the excessively high government taxes that the employer had to pay for each worker. Approximately 400 workers were made redundant. The employers did not replace the employees with AI, even though dressmakers as such are considered as a group affected by advances in AI (Foresight Centre, 2018, p. 23).

Also, as most Estonian employers are small companies, and usually not wealthy, it would be more affordable to hire a handyman once a week or a month instead of buying a solution to apply AI to do a similar job. AI is predicted to have an impact on Estonian electronic and wood industries and the larger trade and service sector.

Estonia has been considered "a front-runner when it comes to encouraging digitalisation." (EESC, 2017a, p. 7) as we have several AI developments which 
have replaced employees. For example, our parcel pickup service, which uses AI instead of human workers, is well known also abroad. As a consumer, you can collect a parcel from the self-service pickup point with a code sent to your telephone, while delivery to the lockers is still made by a human employee. Self-service cash registers have human assistants to help customers in cases the cash register makes mistakes. Estonia is the first country in the world, which started digitalising all family documents and gathering all family and other personal data into one digital register - the Population Register. This means that there is no need for employees to search data from the archives. Digital services in voting, registering your residence, car, school, doctor, applying for the ID card, registering the company, including checking your personal data from the 'e-Riik', or e-Government, has made a number of jobs redundant but this has been regarded as normal development. There are even more services that could be automated, e.g., registering a marriage or divorce, a birth or a death, etc. The important factor here is the quality of the service. AI is intended to operate with no mistakes. Today, however, a rather considerable number of employees are supporting the aforementioned e-services specifically because of the mistakes AI makes.

The Estonian labour market can be characterised also by the trend to work outside the office. Distance working gives the employee flexibility and saves the costs to electricity and tools, including the room rent that the employer is expected to pay. Distance working needs appropriate technological equipment, access to databases and quick tools to communicate with colleagues. While on the one hand AI can be used as a supportive tool for the employee, on the other hand it can also be used as a tool to monitor and control the work of the employee, whether the employee is working, but also to limit working after working hours. Mortensen and Vilella-Vila (2012, p. 672) argue that "also, the tension between flexibility and job security is an issue that should be tackled. Before the crisis deepened, there was already criticism of the EU's flexicurity model as being too much about the 'flexibility' and not enough about the 'security'.'

Distance working and using $\mathrm{AI}$ as a supporting tool raises questions related to the legal responsibility in case of damage, work safety, and others. When an employee has the opportunity to work outside the office, he or she must be responsible for following also the health protection rules - it can actually happen that an employee works even more hours than in the office, in an inappropriate chair and light, checks e-mails in his or her free time, etc. Even when the law allows an employee to be unreachable (see also EESC, 2017a, p. 39), it is tempting to open e-mails on holiday and in 
the evening. Moreover, the new Estonian labour market can be described as an employee without a substitute: when an employee is on holiday, there is no one who would be able to replace that employee. Undoubtedly, the alternative to work from home or summer house helps maintain a better work-life balance, especially when having a sick child at home or a long commute from home to work, only to use a computer in the office. In Estonia, these aspects have not yet been analysed and regulated. Using AI in labour relations requires new cost calculation for labour costs, economic benefits, but also new management styles (EESC, 2017a). Furthermore, using AI could facilitate but also intensify work, demand better self-management on the part of the employee, and raise the question of data protection. For example, in Denmark, non-legally binding guidelines are provided to establish "which type of work should be done and where, e.g., large writing tasks on laptops should not be performed in trains or hotels, where working conditions are ergonomically not ideal" (Eurofound, 2015, p. 51).

Estonia does not have policies related specifically to AI. There are the 1998 Principles of Estonian Information Policy (Plan for the Public Sector), its follow-up documents, the Estonian Information Society Strategy 2007 - 2013 and the Development Plan of Estonian Information Society 2020 (Ministry of Economic Affairs and Communications, 1998, 2007, 2018) but these documents focus basically on Internet access and less on ICT solutions. The aims are declared rather generally in the Plan, referring to the impact on the labour market, while not using specifically the term AI. In relation to the labour market, the Plan predicts high employment rate, suggesting that the use of the smart ICT, new "added value jobs" will be created: about 50,000 new specialists will be working on such positions. Employees can keep their jobs and accept new challenges by renewing their ICT skills. It is noted that jobs without ICT skills are disappearing. Network allows distance working. (Ministry of Economic Affairs and Communications, 2018, p. 15) In 2017, the State Chancellor commissioned from the University of Tartu an analysis 'Future work - new directions and solutions' (Technopolis Group, 2017). The analysis refers to new forms of employment based on the Eurofound 2015 Survey but also other new employment trends in Europe, which should be used in Estonia in the future. The analysis provides an overview and definition of these forms of employment, their international distribution, and their use and distribution in Estonia. It also includes a legal analysis on whether a specific form is in conformity with the Estonian legal system. However, again, the overview and conclusions are too general as they are mostly based on the possibility to use different ICT solutions in hiring an 
employee or doing distance work. The legal analysis was very weak, listing only some provisions set forth in the current Employment Contract Law Act with no suggestions about what should be changed or what legal problems may arise and how to solve them. The general suggestions include new forms of employment but not their relation to AI.

However, in 2018 the Foresight Centre's report 'Labour Market 2035' tackled the impact of technological development on Estonian labour market more specifically. The report supported the idea that some jobs will disappear because of automated solutions, but not all, as some jobs will become more complicated and new jobs will be created. This was explained as normal development because we all support innovative economy as this makes our life more comfortable in general. The report briefly touches upon the question of demographic trends in Estonia and poses a question "Should labour markets try to manage with the current number of people or find new ways to include labour force from other countries?" Estonia does not have many jobs that need low-skilled workers. If there is demand for employment, that would mostly involve middle-skilled or high-skilled workers. The worst thing Estonia can do is to bring workers from outside for a temporary labour market and then realise that such workers are not needed. Sometimes the statements of employers reveal that they do not understand that AI is possible to be used instead of workers - that is, they do not have a whole picture and long-term strategies, and rather just aim for short-term financial profit. This is a situation where the state should foresee future problems, such as the point at which low-skilled workers are no longer needed because of automation. The state should offer today's employers financial support to invest in automation instead of bringing low-skilled workers here from other countries. Estonia is a state, which is open to digitalisation and automatisation in principle. Considering that by 2040 , the working-age population declines to 160,000 , and the percentage of population aged 65 and above increases from 18\% to 27\% (Piirits, 2018, p. 11), Estonia is a state which should consciously invest in AI in labour relations.

European Commission has stated that, the biggest risk for the society is to "be ill-prepared for the future". (European Commission, 2018, p. 2) With no doubt, we cannot prevent AI coming to the labour market, however, we can prepare employees and employers for such transformation. However, according to the Accenture Future Workforce Worker and C-Suite Surveys 2017, employers underestimate the willingness of employees to acquire relevant skills. Employees even are impatient to embrace AI: $62 \%$ of the 
respondents stated that intelligent technologies will create opportunities in their work, $67 \%$ that it will be important or very important to learn new skills to work with intelligent technologies in the next 3 to 5 years, $45 \%$ that AI will help them to do their job more efficiency. (Shook, Knickrehm, 2018, p. 9) Today, digital skills are considered as basic skills alongside literacy and numeracy (European Commission, 2018, p. 7). Digital competencies are described as competence in information and data literacy, communication and collaboration; digital content and creation, safety and well-being, and problem-solving (European Commission, 2018, p. 7). According to the European Digital Skills Survey (European Commission, 2017, p. 21), "advanced digital skills are mostly demanded for professionals (54\% of workplaces), technicians (52\%) and to lesser extent clerical workers (45\%), managers and building workers (31\% of workplaces in both cases) who are required to have this type of digital skills, which they are considered much less important for all other occupations. Specialist digital skills are required mostly for workers employed as professionals and technicians $(43 \%$ and $44 \%$ respectively) and to lesser extent as managers (33\% of workplaces). Advanced and specialist digital skills are very much related to specific sectors (in particular manufacturing and information and communication) and are more likely to be required in larger workplaces." This data proves that AI in its softer nature is in practice and does support employees in different levels of work and not only in labour relations, but in other relations have replaced classical labour relations, too.

\section{CONCLUSION}

The paper delineated the impact of AI on labour market focusing on the labour relations in Estonia. It argued whether such impact will be as disastrous as expected by some scholars, or whether AI is simply a welcomed development for the welfare of the society and markets.

New technologies will change the labour market, giving new jobs and making others just disappear, but this is normal development, not meaning that AI will replace all the employees. Instead, it offers employees better and healthier working conditions. However, employees must be able to retrain themselves, because new jobs demand new skills. Scientific literature and the EU policy documents do not have unified approach to the AI on a labour market. On the one hand, such development of the new technologies is welcomed and seen as an important tool for the economic and societal development. However, on the other hand, there is always a concern about 
the labour force who could lose their jobs. It seems that emphasising the need to retrain by the employees as a normal development should be more powerful. Several analyses prove that AI will enter the labour market more slowly then expected and does not take job positions away from humans, but the job gets adapted so that AI will substitute a human. This needs new skills and the need for new skills is already today to prepare today's employees for new needs. States should support employees and employers specifically on granting new skills. The EU policy supports the idea that new skills are required, and states should consider this in their domestic policies.

When discussing the AI impact on labour relations, one should consider the continuous alteration of offering one's skills and knowledge - it is not only a labour relation, in the labour market new models emerge all the time. In most of the cases, these new models are impacted by the development of technologies, including the AI. Undoubtedly, such models will fracture the classical labour contract, and this will facilitate the taking AI into the use, instead of hiring the employees. However, as discussed above, the changes are not so fast; bringing AI into labour market needs resources and knowledge, and this takes time.

Estonia, as an open society to all kinds of ICT developments, is, on the one hand, open to the $\mathrm{AI}$ in the labour market as it is influenced also by its small population and highly educated people. On the other hand, there are few big industries and therefore the effect replacing an employee by a robot is rather small. However, this has been considered as a normal development and not a big social problem.

Estonian policy documents see the use of smart ICT as a tool to support the development of labour market by creating many new jobs for IT specialists. Former employees must re-skill and then keep their positions. However, the opinion is that there are only few analyses conducted on how AI will affect the future labour market and how to solve the legal questions that new AI supported labour relations can cause. Current analyses are speculative and too general referring that there can be legal problems, but no deeper analyse discussing specific cases which might occur. Estonian state should focus on this problem and deliver more clear positions and solutions. Furthermore, it should be underlined that Estonian case study is very specific due to the fact that across the EU, only Estonia and Italy have less capacity in private sector than public one in terms of the AI implementation. 


\section{REFERENCES}

ACCENTURE. (2017). Accenture Future Workforce Worker and C-Suite Surveys 2017.

ANDERSON, M. (2019). AI and the Future of Work: The Economic Impacts of Artificial Intelligence. [online]. IEEE Spectrum, 2019. Available at: https://spectrum.ieee.org/tech-talk/artificial-intelligence/machinelearning/ai-and-the-future-of-work-the-economic-impact-of-artificialintelligence [Accessed December 10, 2020].

ARNTZ M., GREGORY T., ZIERAHN, U. (2017). Revisiting the risk of automatisation. In: Economic Letters. [online]. Vol. 159, 2017, pp. 157-160. Available at: https://doi.org/10.1016/j.econlet.2017.07.001 [Accessed December 10, 2020].

AUTOR, D. H., LEVY, F., MURNANE, R. J. (2003). The skill content of recent technological change: an empirical exploration. In: The Quarterly Journal of Economics. [online] Vol. 118, No. 4, 2003, pp. 1279-1333. Available at: https://academic.oup.com/qje/article/118/4/1279/1925105 [Accessed March 11, 2020].

BRESLOW, L. (2015). The Pedagogy and Pleasures of Teaching a $21^{\text {st }}$-Century Skill. In: European Journal of Education. [online]. Vol. 50, No. 4, 2015, pp. 420-439. Available at: https://doi.org/10.1111/ejed.12159 [Accessed December 10, 2020].

DAU-SCHMIDT, K. G. (2017). The Impact of Emerging Information Technologies on the Employment Relationship: New Gigsfor Labor and Employment Law. In: University of Chicago Legal Forum. [online]. Vol. 2017, Article 4, 2017, pp. 1-33. Available at: https://chicagounbound. uchicago.edu/cgi/viewcontent.cgi article=1591\&context=uclf [Accessed March 11, 2020].

DAVID, B. (2017). Computer technology and probable job destructions in Japan: An evaluation. In: Journal of the Japanese and International Economies. [online]. Vol. 43, 2017, pp. 77-87. Available at: https://doi. org/10.1016/j.jjie.2017.01.001 [Accessed December 10, 2020].

DECANIO, S. J. (2016). Robots and humans - complements or substitutes? In: Journal of Macroeconomics. [online]. Vol. 49, 2016, pp. 280-291. Available at: https://doi.org/10.1016/j.jmacro.2016.08.003 [Accessed December 10, 2020].

DELPONTE, L. (2018). European Artificial Intelligence (AI) leadership, the path for an integrated vision. [online]. Brussels: ITRE-Committee European Commission, 2018. Available at: http://www.europarl.europa. 
eu/RegData/etudes/STUD/2018/626074/IPOL_STU(2018)626074_ EN.pdf [Accessed March 11, 2020].

EBEL, K. H. (1987). The impact of industrial robots on the world of work. In: Robotics. [online]. Vol. 3, No. 1, 1987, pp. 65-72. Available at: https://doi. org/10.1016/0167-8493(87)90034-9 [Accessed December 10 2020].

EESC. (2016). The changing nature of employment relationships and its impact on maintaining a living wage (exploratory opinion requested by the Dutch presidency). [online]. Available at: https://www.eesc.europa. eu/en/our-work/opinions-information-reports/opinions/changingnature-employment-relationships-and-its-impact-maintaining-livingwage-exploratory-opinion-requested-dutch [Accessed March 11, 2020]. EESC. (2017a). Impact of Digitalisation and the On-Demand Economy on Labour Markets and the Consequences for Employment and Industrial Relations. [online]. Available at: https://www.eesc.europa.eu/en/ourwork/publications-other-work/publications/impact-digitalization-anddemand-economy-labour-markets-and-consequences-employmentand-industrial-relations [Accessed March, 2020].

EESC. (2017b). Artificial Intelligence: Europe needs to take a human-incommand approach, says EESC. [online]. Available at: https://www. eesc.europa.eu/en/news-media/press-releases/artificial-intelligenceeurope-needs-take-human-command-approach-says-eesc [Accessed March 11, 2020].

EUROFOUND. (2015). Sixth European Working Conditions Survey: 2015. [online]. Available at: https://www.eurofound.europa.eu/surveys/ european-working-conditions-surveys/sixth-european-workingconditions-survey-2015 [Accessed March, 2020].

EUROPEAN COMMISSION. (2017).ICT for Work: Digital skillsin the Workplace. [online]. Available at: https://ec.europa.eu/digital-single-market/en/ news/ict-work-digital-skills-workplace [Accessed December 10, 2020].

EUROPEAN COMMISSION. (2018). Communication From the Commission to the European Parliament, the Council, the European Economic and Social Committee and the Committee of the Regions on the Digital Education Action Plan, COM/2018/022 final, SWD(2018) 12 final. [online]. Available at: https://eur-lex.europa.eu/legal-content/EN/ TXT/?uri=COM\%3A2018\%3A22\%3AFIN [Accessed December 10, 2020].

EUROPEAN COMMISSION. (2019a). Ethics Guidelines for Trustworthy AI. [online]. Available at: https://ec.europa.eu/digital-single-market/en/ news/ethics-guidelines-trustworthy-ai [Accessed March 11, 2020]. 
EUROPEAN COMMISSION. (2019b). Shaping Europe's Digital Future. [online]. Available at: https://ec.europa.eu/digital-single-market/en/ economy-society [Accessed December 10, 2020].

EUROPEAN PARLIAMENT. (2019). MEPs approve boost to workers' rights in the gig economy. [online]. Available at: http://www.europarl.europa.eu/ news/en/press-room/20190410IPR37562/meps-approve-boost-toworkers-rights-in-the-gig-economy [Accessed March 11, 2020].

FLEMING, M. (2020). AI Is Changing Work - and Leaders Need to Adapt. In: Harvard Business Review. [online]. Available at: https://hbr.org/2020/03/ ai-is-changing-work-and-leaders-need-to-adapt [Accessed December 10, 2020].

FORESIGHT CENTER. (2018). Labour Market 2035. [online]. Available at: https://www.riigikogu.ee/arenguseire/tooturu-uurimisprojekt/ [Accessed March 11, 2020].

FREY, C. B., OSBORNE, M. A. (2017). The future of employment: How susceptible are jobs to computerisation? In: Technological Forecasting \& Social Change. [online]. Vol. 114, 2017, pp.114, 254-280. Available at: https://doi.org/10.1016/j.techfore.2016.08.019 [Accessed December $10,2020]$.

FUDGE, J. (2007). The New Discourse of Labour Rights: From Social to Fundamental Rights. In: Comparative Labor Law and Policy Journal, Vol. 29, No. 1, 2007, pp. 29-66.

GREEN, J. (2019). 21 Ways AI is Transforming the Workplace in 2019. In: AskSpoke, 2019. [online]. Available at: https://www.atspoke.com/blog/ support/how-ai-is-transforming-workplace/ [Accessed December 10, 2020].

HANDY. (non dated). Be professional with Handy. [online]. Available at: https://www.handy.com/apply?utm_source=home_footer [Accessed March 11, 2020].

HOUTCOOP, W. (2002). Employees with no Certified Skills: How are Technology and Organisational Change Affecting Them? In: European Journal of Education. [online]. Vol. 37, No. 3, 2002, pp. 301-309. Available at: https://doi.org/10.1111/1467-3435.00111 [Accessed December 10, 2020].

HUANG, M. H., RUST, R. T. (2018). Artificial Intelligence in Service. In: Journal of Service Research. [online]. Vol. 3, No. 1, 2018, pp. 155-172. Available at: https://doi.org/10.1177/1094670517752459 [Accessed December 10, 2020]. 
INTERNATIONAL LABOUR ORGANIZATION. (2020). Global Employment Trends for Youth 2020: Technology and the future of jobs. [online]. Available at: $\quad$ https://www.ilo.org/wcmsp5/groups/public/---dgreports/--dcomm/---publ/documents/publication/wcms_737648.pdf [Accessed December 10, 2020].

JARRAHI, M. H. (2018). Artificial intelligence and the future of work: HumanAI symbiosis in organizational decision making. In: Business Horizons. [online]. Vol. 61, No. 4, 2018, pp. 577-586. Available at: https://doi. org/10.1016/j.bushor.2018.03.007 [Accessed December 10, 2020].

KERIKMÄE, T., JOAMETS K., RODINA, A., PLEPS, J., BERKMANAS, T., GRUODYTE, E. (2017). The Law of the Baltic States. Springer Verlag, 2017. [online]. Available at: https://doi.org/10.1007/978-3-319-54478-6 [Accessed December 10, 2020].

KERIKMÄE, T., HOFFMANN, T., CHOCHIA, A. (2018). Legal Technology for Law Firms: Determining Roadmaps for Innovation. In: Croatian International Relations Review. [online]. Vol. 24, No. 81, 2018, pp. 91-112. Available at: https://doi.org/10.2478/cirr-2018-0005 [Accessed December 10, 2020].

KIM, J. Y., KIM, K., LEE, S. (2017). The rise of technological unemployment and its implications on the future macroeconomic landscape. In: Futures. [online]. Vol. 87, 2017, pp. 1-9. Available at: https://doi.org/10.1016/j. futures.2017.01.003 [Accessed December 10, 2020].

MAKRIDAKIS, S. (2017). The Forthcoming Artificial Intelligence (AI) Revolution: Its Impact on Society and Firms. In: Futures. [online]. Vol. 90, 2017, pp. 46-60. Available at: https://doi.org/10.1016/j. futures.2017.03.006 [Accessed December 10, 2020].

MARR, B. (2019). Artificial Intelligence In The Workplace: How AI Is Transforming Your Employee Experience. In: Forbes. 2019. [online]. Available at:https://www.forbes.com/sites/bernardmarr/2019/05/29/ artificial-intelligence-in-the-workplace-how-ai-is-transforming-youremployee-experience/\#71fb0fdb53ce [Accessed December 10, 2020].

MCINTOSH, S. (2002). The Changing Demand for Skills. In: European Journal of Education. [online]. Vol. 37, No. 3, 2002, pp. 229-242. Available at: https://doi.org/10.1111/1467-3435.00106 [Accessed December 10, 2020].

MINISTRY OF ECONOMIC AFFAIRS AND COMMUNICATIONS. (1998). The Principles of Estonian Information Policy. Eesti infopoliitika põhialused (avaliku sektori infoühiskonna kava). [online]. Available at: https://www. mkm.ee/et/tegevused-eesmargid/infouhiskond [Accessed March 11, 2020]. 
MINISTRY OF ECONOMIC AFFAIRS AND COMMUNICATIONS. (2007). Estonian Information Society Strategy 2007-2013. Infoühiskonna arengukava 2007-2013. [online]. Available at: https://www.mkm.ee/et/ tegevused-eesmargid/infouhiskond [Accessed March 11, 2020].

MINISTRY OF ECONOMIC AFFAIRS AND COMMUNICATIONS. (2018). Development Plan of Estonian Information Society 2020. Eesti infoühiskonna arengukava 2020. [online]. Available at: https://www. mkm.ee/et/tegevused-eesmargid/infouhiskond [Accessed March 11, 2020].

MORTENSEN, J., VILELLA-VILA, M. (2012). The future of employment supply and demand in social Europe. In: Futures. [online]. Vol. 44, No. 7, 2012, pp. 671-677. Available at: https://doi.org/10.1016/j.futures.2012.04.006 [Accessed March 11, 2020].

OECD. (2017). Employment Outlook. 2017. [online]. Available at: https://doi. org/10.1787/empl_outlook-2017-en [Accessed March 11, 2020].

PAJARINEN, M., ROUVINEN, P. (2014). Computerization Threatens One Third of Finnish Employment. In: ETLA Brief. [online]. No. 22, 2014. Available at: http://pub.etla.fi/ETLA-Muistio-Brief.22.pdf [Accessed March 11, 2020].

PIIRITS, M. (2018). Foresight Centre. Estonian Labour Market: Current situation and future prognoses. Arenguseire Keskus. Eesti tööturg: hetkeolukord ja tulevikuväljavaated. [online]. Available at: https:// www.riigikogu.ee/wpcms /wp-content/uploads / $2018 / 08 /$ ASK_t\%C3\%B6\%C3\%B6turu_\%C3\%BClevaade.pdf [Accessed March 11, 2020].

PUNIE, Y. (2007). Learning Spaces: an ICT-enabled Model for Future Learning in the Knowledge-based Society. In: European Journal of Education. [online]. Vol. 42, No. 2, 2007, pp. 185-199. Available at: https://doi. org/10.1111/j.1465-3435.2007.00302.x [Accessed December 10, 2020]. PRICEWATERHOUSECOOPERS (PWC). (2002). The Macroeconomic Impact of Artificial Intelligence. [online]. Available at: https://www.pwc.co.uk/ economic-services/assets/macroeconomic-impact-of-ai-technicalreport-feb-18.pdf [Accessed December 10, 2020].

ROE, D. (2018). How AI Is Helping Improve Employee Experiences. In: CMS Wire. 2018. [online]. Available at: https://www.cmswire.com/ digital-workplace/how-ai-is-helping-improve-employee-experiences/ [Accessed December 10, 2020].

SHARMA, A. (2019). How AI can Improve the Future Workplace. In: Towards Data Science. 2019. [online]. Available at: https://towardsdatascience. 
com/how-ai-can-improve-the-future-workplace-5c1c4977f1f [Accessed December 10, 2020].

SHOOK, E., KNICKREHM, M. (2018). Reworking the Revolution. In: Accenture Strategy. [online]. Available at: https://www.accenture. com/t20180613T062119Z_w_/us-en/_acnmedia/PDF-69/AccentureReworking-the-Revolution-Jan-2018-POV.pdf\#zoom=50 [Accessed December 10, 2020].

SPARC. (2013). Strategic Research Agenda for Robotics in Europe 2014-2020. [online]. Available at: https://www.eu-robotics.net/cms/upload/topic_ groups/SRA2020_SPARC.pdf [Accessed March 11, 2020].

SZCZEPAŃSKI, M. (2019). Economic Impacts of Artificial Intelligence (AI). In: European Parliamentary Research Service. [online]. Available at: https:// www.europarl.europa.eu/RegData/etudes/BRIE/2019/637967/EPRS_ BRI(2019)637967_EN.pdf [Accessed December 10, 2020].

UPWORK. (non dated). How it works? An overview of hiring and freelancing on Upwork. [online]. Available at: https://www.upwork.com/i/how-itworks/client/ [Accessed March 11, 2020].

VIOLA, R. (2018). Artificial intelligence, real benefits. In: Blog. 2018. [online]. Available at: https://ec.europa.eu/digital-single-market/en/blogposts/ artificial-intelligence-real-benefits [Accessed March 11, 2020].

WILSON, H. J., DAUGHERTY, P. R., MORINI-BIANZINO, N. (2017). The Jobs that Artificial Intelligence will create. In: MITSloan Management Review. 2017. [online]. Available at: https://sloanreview.mit.edu/article/will-aicreate-as-many-jobs-as-it-eliminates/ [Accessed March 11, 2020].

WRIGHT, S. A., SCHULTZ, A. E. (2018). The rising tide of artificial intelligence and business automation: Developing an ethical framework. In: Business Horizons. [online]. Vol. 61, No. 6, 2018, pp. 823-832. Available at: https:// doi.org/10.1016/j.bushor.2018.07.001 [Accessed March 11, 2020]. 